\title{
CAPITAL, LABOR AND LAWYERS: THE CHANGING ROLES AND RISING INFLUENCE OF THE PITTSBURGH BAR DURING THE GILDED AGE
}

\author{
Ron Schuler ${ }^{*}$
}

ABSTRACT

As lawyers in an American frontier city, Pittsburgh's 19th century lawyers were accustomed, perhaps to a greater degree than their cousins in the large Eastern cities, to being involved with business. Thomas Mellon, founder of the Mellon banking empire, was a lawyer and judge who embodied the entrepreneurial spirit of the Pittsburgh lawyer; and following the Civil War, with the rise of Pittsburgh's industrial power, business-oriented lawyers such as Mellon would be a model for the new corporation lawyer in Pittsburgh-functioning as the intimate business advisor and social peer of tycoons such as Andrew Carnegie, Henry Clay Frick and George Westinghouse. Inevitably, labor organized into unions, in response to the corporatization of capital, and Pittsburgh's first labor lawyer, William Brennen-in a sort of mirror image of the business-oriented corporation lawyers - entered the law after having experienced the inner-workings of a steel mill and participated in the union movement. Pittsburgh's corporation lawyers, however, maintained capital's upper hand against labor - a fact for which the Homestead Strike of 1892 is emblematic - and became among the most influential lawyers in the nation.

\footnotetext{
* Managing Member of the Pittsburgh Office of Spilman, Thomas \& Battle, PLLC. Portions of this article are excerpted from an unpublished work-in-progress, commissioned by the Allegheny County Bar Association, tentatively entitled The Steel Bar: Reinventions of the Legal Profession in an American City of Industry and Commerce, 1788-Present. The author is indebted to Thomas M. Thompson and Bernard Hibbitts for their comments on the unpublished manuscript, and to Samuel I. Yamron for his assistance in finalizing this article for publication.
} 
U N I V E R S I T Y OF P I T T S B U R G H L A W R E V I E W

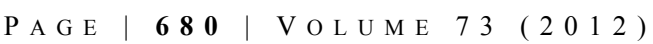

By the end of the 19th century, two great icons stood tall near the corner of Grant and Fifth, pushing skyward through the smoke. The first, completed in 1888, was the new, massive Allegheny County Courthouse and Jail, designed by H.H. Richardson in the image of a Romanesque fortress, with borrowed notes and hints of the grandeur of the Piazza San Marco and the Palazzo Ducale in the city-state of Venice. The complex, built in rugged, pinkish-gray Milford granite, featured a nine-story campanile, topped with a pyramidal roof, and a "bridge of sighs" linking the halls of justice with the county prison over Ross Street. ${ }^{1}$ Seven years later, a block away from the Courthouse door on Fifth Avenue, a steel-framed fourteenstory skyscraper bearing the surname of one of Pittsburgh's great industrialists opened its doors. ${ }^{2}$ The Carnegie Building (actually named in memory of Andrew Carnegie's late brother Thomas) was the headquarters of the Carnegie Steel Company and its many subsidiaries, but it was also a symbol of Pittsburgh's industrial power at the end of the 19th century, an instant example of the combination of the strength and dignity and ambition of steel, on the one hand, and of the corporation as a form of entity, on the other. ${ }^{3}$ These two iconic buildingsdominating the Pittsburgh skyline as they did at that time, standing as solid evidence of both the independent institutional importance and the institutional symbiosis of law and commerce - would have been unthinkable projects before the Civil War. Pittsburgh's own industrial revolution had not only transformed the city's landscape, but it was changing the way law and commerce, eyeing each other warily from either side of Grant Street, would interact.

With that in mind, it is interesting to note that in 1902, there was a Pittsburgh corporate lawyer on the United States Supreme Court (George Shiras, Jr.), a Pittsburgh corporate lawyer on the House Ways and Means Committee (John Dalzell) and a Pittsburgh corporate lawyer serving as United States Attorney General (Philander Knox). Pittsburgh lawyers inhabited powerful positions within each of the three branches of the federal government, and it was anything but a coincidence. Over the prior twenty-five years, Pittsburgh lawyers had played a major role in defining the rules and the culture of the corporation as an institution within American business, as evidenced not only by their parts in the sculpting of the Pennsylvania Railroad and the Carnegie Steel Company-two of the largest

\footnotetext{
1 Martin Aurand, The Spectator And Topographical City 28-35 (Univ. of Pittsburgh Press 2006); LivingPlaces.com, Allegheny County Courthouse, http://www.livingplaces.com/PA/Allegheny_ County/Pittsburgh_City/Allegheny_County_Courthouse.html (last accessed May 4, 2012).

${ }^{2} I d$.

${ }^{3}$ AURAND, supra note 1 , at $36-38$.
} 
business enterprises the world had ever seen — but in countless others. They did so as partners and peers of the great Pittsburgh industrialists, and not only were they well paid for their services, they were often co-founders and co-owners of industrial enterprises. "Men of words" among the Pittsburgh bar were becoming "men of action and property," and in the process they became national leaders-for a time.

Up until the late 19th century-arguably, even later-the ideal of the American lawyer, especially among the bars of the larger metropolitan cities in the East, was that he was a member of a profession, not a trade, and that his principal interest was in justice, not commerce. Cotton Mather, the famed Puritan evangelist from Boston, defined the shape of the American lawyer for many years with what has been called "the First American Address to Lawyers" in 1710:

\begin{abstract}
A Lawyer should be a Scholar, but, Sirs, when you are called upon to be wise, the main Intention is that you may be wise to do Good .... A Lawyer that is a Knave deserves Death, more than a Band of Robbers; for he profanes the Sanctuary of the Distressed and Betrayes the Liberties of the People. To ward off such a Censure, a Lawyer must shun all those Indirect Ways of making Hast to be Rich, in which a man cannot be Innocent ....
\end{abstract}

The gist of Mather's exhortation in Boston, minus the suggestion of a death penalty, was a continual refrain among the leaders of the large Eastern metropolitan bars for decades: for a lawyer to possess the independence that is essential to rendering correct advice and maintaining legal order, he must isolate himself from commercial pursuits. As Superior Court Judge William W. Porter of Philadelphia would write, the office of the old ideal lawyer was "a modest room adorned with book cases where sits a learned semi-recluse writing to bestow his wisdom in the law and satisfied if compensation shall come as an honorarium." "This monastic standard for elite lawyers was a mark of nobility for them, and it was certainly was one of the ways in which a lawyer sought to build a social wall separating himself from the butcher, the blacksmith and the street peddler.

On the Western frontier in places such as Pittsburgh, the wall was not so impenetrable, and the lawyers were not so monastic. Writing of the Western lawyer of the early 19th century, legal historian Lawrence Friedman observes that:

\footnotetext{
${ }^{4}$ CotTOn MATHER, BONIFACIUS: AN ESSAY . . . TO Do GoOD 160-61 (Scholars' Facsimiles \& Reprints 1967).

${ }^{5}$ Robert R. Bell, THe PHiladelphia LaWyer 202 (1992).
} 
U N I V E R I T Y O F P I T T S B U R G H L A W R E V I E W

PAGE

... [I]t was not so easy to scratch out a living in new soil .... Their practice took patience, luck and skill. They did not bother asking what was or was not fit work for a lawyer. Whatever earned a dollar was fair game. . . [H] ard money was at all times scarce; a lawyer who got his hands on some cash would cast around for the most profitable investment. ${ }^{6}$

When Thomas Mellon entered the Allegheny County Bar in 1838, he was entering the profession within a "Western" frontier post that was rapidly blossoming into an "Eastern" metropolis, one in which the identification with Eastern ideals and standards of propriety and the cultural traditions of Western individuality and self-actualization were increasingly at odds. ${ }^{7}$ Certainly there were some Pittsburgh lawyers of the period who viewed law and commerce as appropriately separate arenas, and embraced the Eastern ideal of the monastic lawyer - such as Henry Warren Williams (admitted to the Allegheny County Bar in 1840; Pennsylvania Supreme Court judge, 1868-77), who advised young lawyers that "It is sometimes possible to seek wealth or position for its own sake and find it, but it is not the best or the surest road to either; and it is never wise for a professional man to take the risks of such a course."

In Mellon's vision of the successful lawyer, however, we can see how the ideal of the American lawyer began to change in Pittsburgh in response to the rise of industry, and how aspects of Mellon's own model of American lawyer became the predominant one by the end of the 19th century, even as he left the profession behind to become a full-time capitalist. If the traditional view was that lawyers should separate themselves from commerce, Mellon's view was not only that the most successful lawyers were naturally good businessmen, but also that it was becoming increasingly important within the dynamic economy of Pittsburgh for a lawyer to master the inner-workings of commerce in great detail. In Mellon's view, it appeared, the most fatal weakness of the lawyers of his age was their naiveté concerning the mechanics, methods and motives of commerce.

\footnotetext{
${ }^{6}$ LAWRENCE M. FriedMAN, A History OF AMERICAN LAW 308 (2d ed. 1985).

72 The Twentieth Century Bench and Bar of Pennsylvania 840-41 (H.C. Cooper, Jr., Bro. \& Co., Chicago 1903) [hereinafter Twentieth CEnTURy BenCh AND BAR].

${ }^{8}$ Henry W. Williams, Legal Ethics AND Suggestions For Young COUNSEl 15 (1906).
} 
In his memoir, Mellon writes:

[T]he lawyer's profession embraces the whole field of human nature and the entire scope of human knowledge. He must be intimate with the objects and feelings which actuate the busy world in every department of life. Hence the more comprehensive and clearer his perceptions the better he is calculated to succeed if he possesses the necessary energy to propel him.... He is necessarily a man of the world, mingling with all classes and acquainted with all interests ... ${ }^{9}$

By way of illustration, Mellon relates the story of two brothers, Robert and Andrew Burke, who were admitted to the Allegheny County Bar in 1822 and 1833, respectively:

Robert had the propelling energy which Andrew lacked, and Andrew had the easy flow of eloquence which Robert lacked; consequently Robert accumulated considerable estate although he was in practice comparatively a short time when he died, whilst Andrew remained at the bar for nearly forty years, with more education and acquired accomplishments than his brother, and died in poverty. Robert was an energetic business man and industrious; Andrew had no business tact and was indolent. Robert practiced the law as an active tradesman would his work, whilst Andrew spent his time preparing polished addresses in the few cases in which he was retained. Andrew's adversary would usually gain the case, leaving him but the empty honor of a fine speech. ${ }^{10}$

In other words, Mellon's ideal lawyer was one who embraced the thoughts and habits of the successful businessman, and not necessarily the one who could raise the roof with his oratorical gifts. "I never cared to prepare or deliver a set speech to gain applause," Mellon wrote in his memoir. ${ }^{11}$

We only possess a limited amount of mental power, and the result or product therefrom depends on how it is expended. If unexerted and it remains idle, nothing whatever is accomplished; or if exerted in useless ornamentation and

\footnotetext{
${ }^{9}$ Thomas Mellon, Thomas Mellon And His Times 123 (1994).

${ }^{10} I d$. at 124 .

${ }^{11} I d$. at $126-27$.
} 
U N I V E R I T Y O F P I T T S B U R G H L A W R E V I E W

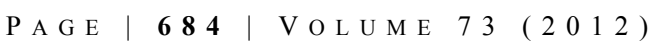

display or other frivolity, a proportionate loss accrues to the clients in the management of their business and to the attorney in the amount of his income. ${ }^{12}$

During an age when a lawyer's showy speeches were prized, Mellon was undoubtedly impatient with and disdainful of the vast majority of his colleagues at the bar.

It was Mellon's opinion that no amount of rhetorical talent as an orator or examiner of witnesses was likely to produce success "unless the lawyer has first made himself acquainted with all the facts and details of the case, even to the minutest circumstance."13 Mellon's habit of pursuing knowledge of Pittsburgh's businesses in great detail is reflected, for example, in his advice to his second eldest son James Ross Mellon on how to learn about business:

... associate with businessmen in different departments and pump them. You recollect Girard's course in that respect. He squeezed all the information out of every man he met like he would a sponge and did it without their suspecting he had any design in it. By appearing communicative and talking about the business and asking questions you can get any man to give information. This information is not about what they are making particularly, for in this they are apt to lie, but as regards the details of the business - the prices - the freights - the risks - the expenses - the amount sales - or amount consumed, etc., etc. Thus, the coal business is important to be known, where the coal comes from, what it costs to mine, the freight, cost of handling, quantity consumed at the gas works and where obtained and by what route, etc. Learn the modus operandi of the business and merchandising and iron business or other important branches of manufacturing .... Remember a young man can never have too much useful information and everything relating to active life is useful nowadays. ${ }^{14}$

Justice Williams, by contrast, had a traditional, somewhat provincial view of the knowledge that a lawyer was required to possess in order to practice effectively. In his Legal Ethics and Suggestions for Young Counsel, Williams acknowledged, like Mellon, that "[t]he practice of law requires a little knowledge of almost every

\footnotetext{
${ }^{12} I d$.

${ }^{13} I d$. at 129 .

${ }^{14}$ David E. Koskoff, The Mellons: The Chronicle of AmericA's Richest FAmily $23-24$ (1978).
} 
trade, art and science in the whole realm of human learning and labor." ${ }^{, 15}$ However, Williams advised young lawyers not to immerse themselves:

But "art is long and time is fleeting" and a lawyer engaged in practice cannot stop his work whenever such a question presents itself and turn his attention to mastery of the details of the branch of labor or of learning thus brought under examination. He needs to be able by some short cut, some comprehensive summary of the subject to leap at once "in media res" and gather up so much of the needed learning as relates to the points in controversy and is therefore indispensable to the proper trial of the cause in which they are presented. ${ }^{16}$

Justice Williams suggested that having dictionaries, digests and encyclopedias on various branches of knowledge on hand was always advisable - a far cry from the investigations and the immersion in the minutiae of business that Mellon personally adopted.

Mellon had also developed disdain for what he perceived as hypocrisy within the profession among lawyers who "pretended to a disregard of money and exhibited contempt at its accumulation." "17 Perhaps the most telling evidence of his impatience with the legal profession turns up in his later advice to his sons. When his son James expressed an interest in entering a lawyer's office as a clerk, Mellon cautioned that after six months he would probably learn all that was important, and that there were more lucrative pursuits. In order to succeed in the law, Mellon told his son, one required

... first class business talents; but if pecuniary success is the object first class business talent can mostly be utilized to better advantage in other pursuits: especially is this the case if the party has any capital of his own to operate with ... Attention to other people's business is a waste of time when we have profitable business of our own to attend to ... 18

\footnotetext{
${ }^{15}$ WILLIAMS, supra note 8 , at 75 .

${ }^{16}$ Id. at $75-76$.

${ }^{17}$ Mellon, supra note 9, at 128.

${ }^{18}$ KosKoff, supra note 14 , at 23.
} 
U N I V E R I T Y OF P I T T S B U R G H L A W R E V I E W

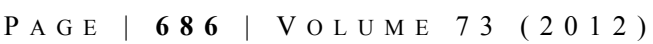

One gets the sense from his letters and memoir that Mellon was only too happy to leave behind the practice of law in an age in which a lawyer's need to understand the business of Pittsburgh was not fully appreciated or understood.

Mellon was elected to the Allegheny County Court of Common Pleas in 1859 and served one ten-year term. ${ }^{19}$ Upon his retirement from the bench at the age of 57, with "two bright boys just out of school," Judge Mellon "concluded to open a banking house" rather than going back into the practice of law. ${ }^{20}$ On January 2, 1870, Judge Mellon opened the T. Mellon \& Sons Bank with two of his younger sons, Andrew and Richard, in a building at 514 Smithfield Street. ${ }^{21}$ His acumen and stewardship successfully guided the Mellon Bank through the Panic of 1873, in which more than fifty of Pittsburgh's banks failed, and he made shrewd investments in downtown real estate and coal, as well as a $\$ 10,000$ loan to Henry Clay Frick which enabled Frick to provide coke for Andrew Carnegie's steel mills. ${ }^{22}$ In time, under Judge Mellon's leadership, the Mellon Bank as one of the strongest and most stable banks in the region, and the Bank ultimately contributed to the launch of such corporations as Gulf Oil Corporation, the Aluminum Company of America, Koppers Company, Pittsburgh Coal Company, the Carborundum Company, the McClintic-Marshall Construction Company, and many others. ${ }^{23}$

Mellon's habits of mind, his obsession with the intricacies of Pittsburgh business, were also being taken on by younger practitioners in Pittsburgh after the conclusion of the Civil War. Even before Mellon exited both law and finance, the major lines of discussion and debate among members of the bar were shifting away from the nature and powers of the State, to the nature and powers of the Corporation. Thus, a new generation of Pittsburgh lawyers, born right into a time and place of explosive change at the noisy nexus of Pittsburgh law and Pittsburgh commerce that was encouraged in no small part by the Mellon Bank itself, were developing business acumen out of necessity - some of them, inevitably, in the likeness of Thomas Mellon. Far from being separate from commerce, far from being encouraged to gain a mere dilettante's command of business, far from being impartial about the forms and institutions of business - the new model of

\footnotetext{
${ }^{19}$ Twentieth Century Bench And BAR, supra note 7, at 840-41; Mellon, supra note 19, at 223.

${ }^{20}$ Mellon, supra note 9, at 244.

${ }^{21}$ Twentieth Century BenCh AND BAR, supra note 7, at 840-41; MeLlon, supra note 8, at 223.

${ }^{22} I d$.

${ }^{23} I d$.
} 
Pittsburgh lawyer that began to emerge after the Civil War would absorb and adopt the principles and objectives of business, and would be a leader in the creation of the corporation culture of Pittsburgh. Men like John Dalzell, D.T. Watson, George Shiras, Willis F. McCook, Philander Knox and James H. Reed were examples, to varying degrees, of this model, and they helped to make the Pittsburgh bar a forceful institution during the period. Each of them became wealthy in the process.

The domain of this new generation of Pittsburgh lawyer was the Corporation. The first modern, complex business institutions in America, and in Pennsylvania in particular, were railroads, and railroads became America's first important corporations. As Alfred D. Chandler, Jr. writes in Jack Beatty's compilation Colossus:

The men who managed these enterprises became the first group of modern business administrators in the United States. Ownership and management soon separated. The capital required to build a railroad was far more than that required to purchase a plantation, a textile mill, or even a fleet of ships. Therefore, a single entrepreneur, family, or small group of associates was rarely able to own a railroad. Nor could the many stockholders or their representatives manage it.... Only in the raising and allocating of capital, in the setting of financial policies, and in the selection of top managers did the owners or their representatives have a real say in railroad management. ${ }^{24}$

As Chandler suggests, the existence of the nation's railroads depended, to a large degree, upon the indulgences provided by the corporate form of entity; principally, the ability to raise a large amount of passive equity capital while affording the investors with a "veil" of insulation from the corporation's liabilities. The trick of the veil enabled the railroad tycoons of the era to enlarge the scale of private industry in ways that would have been unimaginable without it.

Not surprisingly, the most important railroad in Pennsylvania, the Pennsylvania Railroad, was founded and organized as a corporation, on April 13, $1846 .{ }^{25}$ By 1880 , with 30,000 employees and $\$ 40$ million in capital, the Pennsylvania Railroad was the world's largest corporation, and it was a center of

\footnotetext{
${ }^{24}$ Alfred D. Chandler JR., The Visible Hand: The Managerial Revolution in American BUSINESS 87 (1977).

${ }^{25} 2$ William Bender Wilson, History of the Pennsylvania Railroad Company: With Plan of ORganizATION, PORTRAITS OF OFFICIALS AND BIOGRAPHICAL SKETCHES 8 (1895).
} 
political power in Pennsylvania. ${ }^{26}$ The old joke was that the legislature of Pennsylvania only adjourned when the Pennsylvania Railroad had no more business for it to transact.

In Pennsylvania, beginning in the 18th century, corporate charters were granted solely by a special act of the legislature, and often only for a community activity, such as the building of a bridge. As Sell and Clark observe, such special legislation "was but a trickle in the legislative stream at the beginning of the 19th century," but "by the time of the Civil War reached full flood proportions," meaning that private parties were becoming increasingly active in soliciting corporate charters from the legislature..$^{27}$ By 1872 , the situation was out of hand: out of 1,193 acts passed by the Pennsylvania legislature that year, 1,145 of them were pieces of special legislation, the vast majority of which were for the creation of private corporations, and only 48 of the acts were pieces of general legislation. ${ }^{28}$ Reformers complained that corporate charters were held out as cherries by lobbyists, bought and paid for as favors from corrupt legislators, and they agitated for a new system. The Pennsylvania Constitutional Convention of 1873-spurred on by the excesses of publicly-financed private corporate charters that had been granted to the railroad companies - voted to ban all special legislation creating corporate charters, clearing the way for the enactment of the Corporation Act of 1874, which provided that for-profit corporations could be created by the simple act of filing a corporate charter with the State. If there were reformers who were suspicious of corporations generally, however, the reforms of 1873 and 1874 succeeded only in multiplying the number of Pennsylvania corporations.

In the model of the "Pennsy," the successful iron and steel entrepreneur of Pittsburgh - a man such as Henry Clay Frick (the former coke entrepreneur who became manager of Carnegie's operations), Benjamin Franklin "B.F." Jones, Sr. (the founder of Jones \& Laughlin) or Henry W. Oliver (of the Oliver Iron and Steel Company) — would deploy vast amounts of private, passive equity capital to erect his own vertically integrated enterprise. Such a corporation, as James Howard Bridge describes in his "inside" history of Carnegie Steel, assembled "its own mines, dug its ore with machines of amazing power, loaded it onto its own steamers, landed it at its own ports, transported on its own railroads, distributed it

${ }^{26}$ Bruce Bomberger \& William A. Sisson, Made in Pennsylvania: An Overview OF The Major HISTORICAL INDUSTRIES OF THE COMMONWEALTH 26 (1991).

${ }^{27} 2$ W. EdWard Sell \& William H. Clark, JR., PenNSYlvania Business Corporations $\S 2.3 .2$, at 6 (2d ed. 1998).

${ }^{28}$ Rosalind L. Branning, Pennsylvania Constitutional Development 41 n.22 (1960). 
among its many blast-furnaces, and smelted it with coke similarly brought from its own coal-mines and ovens, and with limestone brought from its own quarries" and consolidated "these disorganized units into a solid, compact, harmonious whole, whose every part worked with the ease and silent motion of the perfectly balanced machine. $" 29$

The emerging rules of governance under these forms of existence required that commercial decision-making was to be done in a collective manner, with the deliberation and assent of a group of stakeholders in the enterprise through a set of agreed-upon procedures, thus giving dimension to a fiction that has become a bedrock assumption of American legal ontology today: a partnership is, and a corporation to a greater degree is, a person - with the ability to act, the right to pursue claims, and the capacity to have claims pursued against it. These chimerical forms of existence inevitably required their own legal counselors, skilled in the arcane application of the fiction to every-day commercial reality.

Pittsburgh's corporation lawyers would fall in with that "ease and silent motion" described by Bridge, but for a variety of reasons-because lawyers were generally well-educated, because they were affluent, and because the corporation itself was a legal device that required a lawyer's care and feeding - they often did so as the peers of Pittsburgh's increasingly sophisticated industrialists. Unlike many of the managers and superintendents employed by these industrialists, who passed messages back and forth to the top executives via middle managers, the top lawyers dealt directly with the top industrialists with a candor that would have been unbecoming for an underling.

For example, when Henry Clay Frick sought advice from D.T. Watson regarding his equipment and supply sales activities, Watson was as blunt as an elder brother: "Your H.C. Frick Coke Company," Watson wrote,

has no power to legally engage in the purchase and sale of general merchandise. You have taken out a charter for the Union Supply Co. Ltd. It has no capital but you use its name as a mere cover for doing "what your company cannot do legally." Pay in the capital stock and make your Union Supply a legal corporation. $^{30}$

\footnotetext{
${ }^{29}$ James Howard Bridge, The Inside History of the CARNEgie SteEl Company 169 (1903).

${ }^{30}$ FrANCIS R. HARBISON, D.T. WATSON OF COUNSEL 48 (1945).
} 
U N I V E R S I T Y O F P I T T S B U R G H L A W R E V I E W

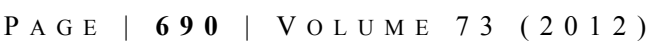

George B. Gordon (1860-1927; admitted 1883), one of John Dalzell's junior partners and later the head of the successor firm of Gordon \& Smith, was known to have enjoyed working sessions with such tycoons as Andrew Mellon and Alcoa's Arthur Vining Davis, sitting by while they read long, complicated contracts or briefs and discussing the essential points and weaknesses of them. ${ }^{31}$ Some of these corporation lawyers would participate even more directly in the affairs of their commercial colleagues. Willis F. McCook (1851-1923; admitted 1876 after serving his preceptorship with Hampton \& Dalzell), who was captain of the Yale Bulldogs' first-ever football squad before returning to Pittsburgh and becoming Frick's personal business lawyer, was among the seven co-founders, an initial investor, general counsel, and ultimately a president and chairman, of Wallace $\mathrm{H}$. Rowe's Pittsburgh Steel Company, one of the antecedents of Wheeling-Pittsburgh Steel.

The peerage of executives and lawyers during Pittsburgh's Gilded Age also manifested itself in their social relations. In June 1873, an exclusive "voluntary association" called the Duquesne Club was founded by eleven Pittsburgh industrialists "where," as George Shiras III put it, "dinners and banquets could be held more privately than in a hotel." $" 32$ By the 1890s, the Club had its own building on Sixth Avenue, a handsome Romanesque brownstone designed by a successor to the architectural firm of H.H. Richardson, who had designed the Courthouse.

An illustrious group of industrialists and lawyers founded an even more exclusive "club within a club" called the "Number Six Club" that lunched every day in Room Number 6 of the Duquesne Club. ${ }^{33}$ These men included Thomas Carnegie, Andrew's talented brother; Henry Oliver; Charles L. Fitzhugh, a former Union Army general and president of Shoenberger Steel, along with his brother and financial manager, Robert; John H. Ricketson (1836-1900; came to Pittsburgh in 1861), a lawyer who had assumed control of his father-in-law's business, the Pittsburgh Foundry; B.F. Jones, Sr.; John Chalfant, one of the fathers of the Pittsburgh steel industry and a manufacturer of steel tubing, along with his partners Charles Spang and Campbell Herron; the iron broker Albert H. Childs; another iron manufacturer, Maxwell K. Moorhead; A.E.W. Painter of the J. Painter \& Sons Iron Works, later president of the People's National Bank; Judge William G. Hawkins of the Orphans Court; corporate lawyers Solomon Schoyer, Jr. (1832-1911;

\footnotetext{
${ }^{31}$ ChARles C. CARr, ALCOA AND AMERICAN ENTERPRise 49 (1952).

${ }^{32}$ George Shiras, JR., Justice George Shiras, Jr. OF PittSburgh 69-70 (Winfield Shiras ed., 1953).

${ }^{33}$ Winfield ShiRAs, Justice GeORge ShiRAs JR. OF PitTsburgh 79 (Univ. of Pittsburgh Press 1953).
} 
admitted 1857) and George Shiras, Jr. (1832-1924; admitted 1855); Captain Frank H. Phipps, a high-ranking ordnance officer and later the commandant of the Pittsburgh Arsenal; and Henry S.A. Stewart, an oil and real estate magnate. ${ }^{34}$ While soot from the steel mills blackened Pittsburgh's downtown streets outside, the mustachioed men of the Number Six Club dined, smoked cigars, and discussed the nation's business.

Ricketson, as a lawyer sharing the disdain of Pittsburgh's industrialists for government intervention in their business, would often accompany Jones or Chalfant to Washington to lobby before a congressional committee against some new intrusion. Shiras counted Chalfant and Childs as particularly close friends; Childs was his younger fraternity brother at Yale, and Shiras would take a weekly Sunday walk with Chalfant, "often crossing the bridge from Allegheny bridge and tramping through the deserted streets of downtown Pittsburgh," according to George Shiras III. ${ }^{35}$

Later, Philander Knox and James H. Reed, the founders of the law firm that has become Reed Smith, were among the regular attendees of Henry Clay Frick's poker nights, along with Judge Mellon's son Andrew, George Westinghouse and Robert Pitcairn, superintendent of the Pennsylvania Railroad. ${ }^{36}$ Frick's poker companions, Andrew Carnegie, and other members of the Number Six Club were prominent members of the South Fork Fishing and Hunting Club, the club that later became notorious for its alleged role in the Johnstown Flood of 1888. Other Pittsburgh lawyers who frequented the Club along with the "pig-iron aristocracy" of the day included Hilary B. Brunot; Cyrus Elder, chief counsel for the Cambria Iron Company; Westinghouse's patent advisor George Christy; Alexander C. Crawford; and Major James McGreggor. ${ }^{37}$

The Pittsburgh lawyer's social standing gave him the ability to leave his imprint on the corporation culture of the age, but he was also required to be a thoughtful leader, particularly with respect to the metaphysical questions of the status and the powers of the corporation - the shape of the corporate soul - that inevitably arose in dealing with the states that created them.

\footnotetext{
${ }^{34} I d$. at 77.

${ }^{35} \mathrm{Id}$. at 80 .

${ }^{36}$ Quentin R. Skrabec, JR., George Westinghouse: Gentle Genius 9 (2007).

${ }^{37}$ DAvid McCullough, The Johnstown Flood 58-59 (1968).
} 
U N I V E R S I T Y OF P I T T S B U R G H L A W R E V I E W

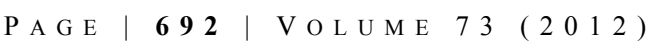

The Pittsburgh corporate lawyer was also called upon to be a field marshal and strategist in the heat of the moment. During the Railroad Riots of 1877, for example, striking railroad workers first shut down operations at the Pennsylvania Railroad yards in the Strip District; and when they were fired upon by a Philadelphia-based regiment of the Pennsylvania Militia, they burned most of the Railroad's property, including the Depot, to the ground. ${ }^{38}$ In the deep background of the Railroad Riots, the Pittsburgh corporate counsel for the Railroad, John Henry Hampton and John Dalzell, were busy shuttling between the Mayor's Office, the County Sheriff, and General Albert Pearson, the commander of the Pittsburgh regiments of the Militia and a former Allegheny County District Attorney, pushing out directions from the Railroad on the next tactical moves against the street mobs. 39

During the Railroad Riots, however, neither the Railroad nor the workers fared very well. The Railroad was not prepared for mass civil disobedience, and the workers were mostly disorganized - a mob without leadership or a plan to address management on the steep wage cuts that had precipitated the Riots. By the time of the infamous Homestead Strike, both labor and capital had matured. As the first president of the Allegheny County Bar Association, Adam Mercer Brown said in his inaugural address in 1871, "Organization is the great industrial, commercial and professional lever of the age" begin to arrange itself in the likeness of the corporations it challenged, through the creation of union organizations, such as the Sons of Vulcan, the Knights of Labor, and the Amalgamated Association of Iron and Steel Workers.

It remained for a Pittsburgh lawyer to become their champion. Interestingly, in the mirror image of the businessman-lawyers who were dominating the elite corporate bar in Pittsburgh, Pittsburgh's first labor lawyer was a laborer.

William J. Brennen (1851-1924) had, by 1877, lived most of his life in the shadow of the American Iron Works of the Jones and Laughlin Steel Company on the South Side of Pittsburgh. ${ }^{41}$ His father, John Brennen, was a millwright in the Iron Works; and as the eldest of thirteen Brennen children, William left public school at age 11 and went to work as a "pull up boy" in the Jones \& Laughlin

\footnotetext{
${ }^{38}$ RoBert BRUCE, 1877: YeAR OF VIOLENCE 144-47, 166-68 (1989).

${ }^{39} I d$.

${ }^{40}$ A.M. Brown, Pittsburgh Law Association-Address of A.M. Brown, Esq. (Apr. 5, 1871), in 18 PitTSBURGH L.J. 32, 1871, at 252.

${ }^{41}$ W.J. Brennen Passes Away After Attack of Pneumonia, PitTSBuRgh Post, Apr. 16, 1924, at 3.
} 
machine department. He left the Iron Works briefly at 15 to attend a Christian Brothers school, but rejoined the Works as a machinist's apprentice, continuing his education by helping to establish the Mechanics' Library—reading, studying and debating the avid young men who collected there. In addition to his debating skill, the barrel-chested Brennen was also known as the strongest man for his weight at the J\&L mill, with a pair of speedy fists when the occasion would demand.

By 1872 , Brennen had become a capable machinist and was presented with a kit of tools by the Iron Works, although he received a temporary setback when he lost the sight in one eye after the breaking of a drill sent a piece of steel into it. Indefatigable and unmarried (he would remain so for his entire life), he found time to teach night school to fellow ironworkers, prepared a manual for fellow machinists called The Machinist's Guide, and became captain of the Ormsby Hose Company, a volunteer fire company on the South Side, as well as president of the South Side branch of the No Rent Manifesto Land League, a group formed to protest the imprisonment of the Irish nationalist Charles Stewart Parnell by the British. ${ }^{42}$ Brennen's love of debate had spurred him to become involved with Democratic Party politics, and at 24, the bright, articulate young man had served as one of the youngest delegates to the 1876 Democratic National Convention in St. Louis that had nominated Samuel Tilden for president.

Brennen, however, carried on the fight by getting elected City Council in 1878 on the Democratic-Labor ticket, and immediately becoming minority leader. ${ }^{43}$ In 1880, he ran for the Board of Aldermen and was declared the loser; however, alleging fraud at the polls, he engaged a lawyer and managed to be seated after waging what turned out to be a three-year legal battle. Assuming leadership within the Democratic Party on the South Side, Brennen very publicly fought the battle, to borrow a phrase from historian Paul Krause, of mobilizing Pittsburgh's workers "to wrest the reins of government from the supporters of 'organized capital."”

Hand-in-hand with entering local politics, Brennen also assumed leadership within the labor circles. He served as president of the Machinists' and Blacksmiths' Union, helping to merge it with the Knights of Labor, and established the Knights of Labor Local 731; he was a delegate to the 1881 International Trades and Labor Congress in Pittsburgh; and in 1883 he served as the clerk to the U.S. House of Representatives' first-ever Committee on Labor, which was being chaired by James Herron Hopkins, a Democrat. During Brennen's ongoing Aldermen election battle,

${ }^{42} I d$.
${ }^{43} I d$. 
U N I V E R S I T Y OF P I T T S B U R G H L A W R E V I E W

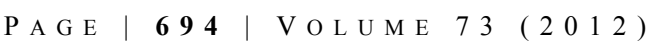

however, Brennen became fascinated by the machinations of the law; and in July 1884, Billy Brennen became a member of the Allegheny County bar, joining his preceptor, J.K.P. Duff as the junior partner of the firm of Duff \& Brennen. Almost immediately, in addition to being considered to be an expert in election law (and subsequently serving as counsel to the Democrats in almost every important election controversy in Pittsburgh for a number of years), Billy Brennen became labor's first advocate within the bar of Pittsburgh. ${ }^{44}$

Being Pittsburgh's labor advocate, in Brennen's case, meant fulfilling a variety of roles. It meant being the steward of the organizational machinery of the new entities, the labor unions, that were being born during the period in response to, and in the mirror of, the corporations that were their adversaries, becoming counsel to the Amalgamated Association of Iron and Steel Workers, the American Flint Green Bottle Glass Workers and the United Coal Miners' Union, among others. More importantly, however, being labor's advocate meant helping to define, by shades and degrees, the manner and methods of organized labor's argument with organized capital during a time when labor still had almost no tools recognized by statute or by common law at its disposal. Even the right to strike itself was an unsettled question; despite the fact that the Pennsylvania legislature had passed laws in the 1870s purporting to protect the right to strike, Pennsylvania courts would continue to define most labor organization activities as criminal during the $1880 \mathrm{~s}^{45}$

In 1888, Brennen represented alleged agents of the Knights of Labor in a case involving one of the nascent techniques of organized labor, the boycott. In what became known as the "Brace Boycott Case," the Brace Bros. Laundry had discharged 11 young girls out of a staff of 90 who worked in its steam plant. The agents demanded that the girls be reinstated or "it would be to the injury, if not the ruin, of plaintiff's business." Soon thereafter, the agents began to hand out circulars detailing the firing of the girls and asking patrons to cease doing business with Brace Bros.; followed the Brace Bros. wagons, noted down their customers, and paid personal visits to them to dissuade them from dealing with Brace Bros.; put a big sign in a window of a Pittsburgh building reading "Headquarters Brace Bros. Boycott Committee"; drove buggies through the streets with banners on each side

\footnotetext{
${ }^{44}$ Michael P. Weber, Don't Call Me Boss: David L. Lawrence, Pittsburgh's Renaissance MAYOR 11-14 (1988).

${ }^{45}$ Paul Krause, The Battle for Homestead 156-59 (1992).
} 
reading "Boycott Brace Bros." and generally harassed the Brace Bros. wagon drivers wherever they found them. ${ }^{46}$

Judge Jacob F. Slagle, in an exhaustive opinion in Common Pleas Court, ruled in favor of Brace Bros.' request for an injunction against the agents on the grounds of overt acts of intimidation and coercion on the part of the defendants that "tend[ed] toward violence"; but significantly, the court would not rule on, and left open the possibility that, "the defendants in this case might, individually or collectively, refuse to employ Brace Bros., and advise their friends and neighbors and such of their patrons as they could reach, not to do so, or ... distribute circulars, giving a truthful account of plaintiffs' trouble with their employees.",47

In McCandless \& Kinser v. O'Brien, Brennen argued and the court held that an organization of workingmen formed to secure the payment of higher wages was not, in and of itself, unlawful, but when "by words and acts, their numbers, their manner, their movements, by annoyance and intimidation, the members of such an organization undertake to practically compel other workmen to cease work, they are guilty of acts which constitute a nuisance and they may be enjoined." 48

For Billy Brennan, any progress in defining the manner and method of the protests of organized labor was a matter of two steps forward, one step back-an exercise in puncturing pinpricks in the notion, deeply embedded in Pennsylvania law, that "labor was 'a vendible commodity,' like beans or potatoes," as James Mellon has observed, and that organized labor was an illegal conspiracy to fix commodity prices. ${ }^{49}$ Brennen's persistence, at a time when the Pittsburgh Legal Journal did not even recognize "Labor Law" as an index category, was a drumbeat that kept the concerns of organized labor in the daily conversation, in the courtrooms as well as the newspapers of Pittsburgh. Through the sum total of his work, he was conjuring up a refined, decriminalized vision of what a strike might look like.

In contrast to the disorganized mob in the Pennsylvania Railroad yard in 1877, the workers at the Homestead Steel Works of the Carnegie Steel Company in 1892 were organized in a strong national union, the Amalgamated Association of

\footnotetext{
${ }^{46}$ See 18 PitTSBurgh L.J. 399 (1888); Brace v. Evans, 3 Ry. \& Corp. L.J. 561 (Allegheny Co., Pa. Com. P1. 1888).

${ }^{47} I d$.

${ }^{48}$ See 12 Pennsylvania Courts, The District Reports of CASes DeCided in All the Judicial Districts OF THE STATE OF PENNSYLVANIA 556 (1913).

${ }^{49}$ Mellon, supra note 19, at 296.
} 
U N I V E R S I T Y OF P I T T S B U R G H L A W R E V I E W

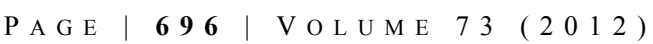

Iron and Steel Workers; and the union was directed by a president, William A. Weihe, and represented by counsel, Billy Brennen. On the side of Carnegie Steel, the battle was to be directed by its chairman, Henry Clay Frick, and his boyhood friend and attorney, Philander Knox.

While Brennen was slowly, methodically defining the limits of union activity in Pittsburgh, one case at a time, Frick, Knox and Carnegie Steel (with advice from Andrew Carnegie, enjoying semi-retirement in Scotland) had been developing what had been, up until the summer of 1892, a successful strategy for busting unions. ${ }^{50}$ Prior to the expiration of a union contract on wages, management would announce its intentions to refuse to negotiate with the union, to lower the wage scale, and to shut down the operation unless individual workers signed new "iron clad" agreements with the company. ${ }^{51}$ If the union decided to force a lockout, the union would typically follow up by blocking the entrances to the plant in order to make sure that management would be unable to bring in replacement workers. $^{52}$ Management would then counter by bringing in sheriff's deputies or hired detectives to guard the replacement workers as they entered the plant, thereby bringing the union to its knees. ${ }^{53}$ Carnegie had followed this strategy in the successful defeat of the Knights of Labor at the Edgar Thomson Works in Braddock in 1889, and Frick and Knox had deployed hired Pinkerton detectives in February 1891, when 10,000 coke workers went on strike against the H.C. Frick Coke Company, a joint enterprise of Frick and Carnegie, in Connellsville. ${ }^{54}$

On July 6, 1892, while Brennen's advice filtered down through the Advisory Committee of the Amalgamated Association in Homestead, Knox was conferring with the County Sheriff, William H. McCleary, regarding the launch of two barges, containing three hundred Pinkerton detectives, down the Monongahela River toward Homestead. Neither the plans of Brennen nor the plans of Knox would prevail, however; when the barges arrived at Homestead, the workers and residents of Homestead turned into an angry mob and attacked the barges. The Pinkertons returned fire, but in the ensuing gun battle, they faltered, and ended up surrendering

\footnotetext{
${ }^{50}$ See David Nasaw, Andrew Carnegie 322-33 (2006); Les Standiford, Meet You in Hell 76-77 (2005).

${ }^{51} I d$.

${ }^{52} I d$.

${ }^{53} I d$.

${ }^{54}$ See NASAW, supra note 50, at 322-33; STANDIFORD, supra note 50, at 76-77; KRAUSE, supra note 45 , at 236-37.
} 
to run a brutal gauntlet of Homestead townspeople. In all, among both workers and detectives, thirteen people died and 36 were wounded, and no replacement workers made it through the gates of the mill on that day. Depictions of the horrors of the battle of Homestead were emblazoned on the nation's newspapers, largely cast as a reminder of the cold greed of the tycoons.

Having won the battle, however, the Amalgamated quickly found itself losing the war. Four thousand soldiers from the Pennsylvania state militia arrived a few days later at the request of Sheriff McCreary and surrounded the plant, displacing the strikers. While strike leaders were fighting criminal conspiracy charges levied by officials who were sympathetic to Frick, the Amalgamated struggled on with a diffuse, ineffective protest through the summer, eventually voting to conclude the strike and return to work in November $1892 .{ }^{55}$ Outmaneuvered by Frick and Knox and their political influence, Weihe, Brennen and the union were crushed at the Homestead Steel Works; and thereafter, while unions survived in Pittsburgh, they were essentially powerless, relative to the peak of their success in the Steel Valley, until well into the 20th century. The Amalgamated Association, after its defeat at Homestead, shrank from 24,000 members in June 1892 to 10,000 members by $1898 .^{56}$

The Pittsburgh corporations and their tycoons had survived the Railroad Riots and the Battle of Homestead. They had survived the wrath of public opinion after the Johnstown Flood, in which the dam owned by the South Fork Fishing and Hunting Club burst in 1888, destroying the city of Johnstown, among others, and killing over 2,200 people. ${ }^{57}$ They had even survived internecine squabbles, such as the rift between Frick and Carnegie that arose in 1900 and mushroomed into the "Greatest Lawsuit Ever," after which Carnegie sold his steel interests to J.P. Morgan, resulting in the formation of the United States Steel Corporation in $1901 .^{58}$ Pittsburgh's corporate lawyers were intimately involved in every one of these dramatic events, playing a significant role in guiding the Pittsburgh corporations and their tycoons, if not to success in all cases, at least to the avoidance of ruin. It was no wonder that the elite corporate lawyers in the Pittsburgh bar were considered, at the end of this grand run in 1902, worthy of occupying three of the

\footnotetext{
${ }^{55}$ KRAUSE, supra note 45 , at 236-37.

${ }^{56}$ Jesse S. Robinson, The Amalgamated Association of Iron, Steel and Tin Workers: A Study in Trade Unionism (1917) (unpublished Ph.D. dissertation, The Johns Hopkins University) (on file with the Library of The Johns Hopkins University).

${ }^{57}$ See generally MCCULLOUGH, supra note 37, at 58-59; NASAW, supra note 50, at 322-33.

${ }^{58} I d$.
} 
U N I V E R S I T Y O F P I T T S B U R G H L A W R E V I E W

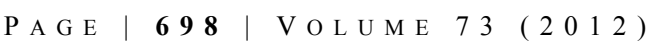

most influential legal positions in Washington - one in each branch of the federal government.

The year 1902 was the high water mark for the national influence of the Pittsburgh lawyer, and it was also the year which showed portents for the struggles that Pittsburgh lawyers would endure in the future. In that year, President Theodore Roosevelt came to Pittsburgh to deliver a speech at a Fourth of July celebration in Schenley Park, with Attorney General Philander Knox at his side. There the President uttered sentiments that would resound in one form or another in the ears of Pittsburgh lawyers for decades: "Especially great, especially difficult," the President said,

are the problems caused by the growth and concentration of great individual, and above all, great corporate fortunes. It is immensely for the interests of this country that there should be such individual and corporate wealth as long as it is used right, and when not used right then it becomes a serious menace and danger. $^{59}$

The audience gathered there applauded, and what followed, under Roosevelt and later presidents, were a series of significant, far-reaching progressive reforms in labor and antitrust laws that would keep Pittsburgh lawyers in the middle of the fray, if out of the limelight, for decades thereafter.

${ }^{59}$ Crowds in Pittsburg Cheer the President, N.Y. TIMES, July 5, 1902, available at http://query.nytimes .com/mem/archive-free/pdf?res=F20713FB3A5F12738DDDAC0894DF405B828CF1D3 (last accessed May 5, 2012). 